\title{
Functional integrity of Colossoma macropomum (Cuvier, 1816) sperm cryopreserved with enriched extender solutions
}

\author{
Raycon Roberto Freitas Garcia ${ }^{1}$, Ana Carina Nogueira Vasconcelos ${ }^{1}$, Jayme Aparecido \\ Povh $^{2}$, Eneder Rosana Oberst ${ }^{1}$, Antonio Sérgio Varela Jr. ${ }^{3}$, Carine Dahl Corcini ${ }^{4}$ and \\ Danilo Pedro Streit Jr. ${ }^{1}$
}

Cryoprotectant solutions are used to protect the sperm from alterations caused by the low temperature in the cryopreservation process. We evaluated the quality of Colossoma macropomum semen after freezing, using dimethyl sulfoxide (DMSO) as a cryoprotectant, combined with two extender solutions (T1 - Solution 1: Glucose $90.0 \mathrm{~g} / \mathrm{L}$, Sodium Citrate $6.0 \mathrm{~g} / \mathrm{L}$, EDTA 1.5 $\mathrm{g} / \mathrm{L}$, Sodium Bicarbonate $1.5 \mathrm{~g} / \mathrm{L}$, Potassium Chloride $0.8 \mathrm{~g} / \mathrm{L}$, Gentamycin Sulphate $0.2 \mathrm{~g} / \mathrm{L}$, and T2 - Solution 2: Glucose $90.0 \mathrm{~g} / \mathrm{L}, \mathrm{ACP}^{\circledR}-10410.0 \mathrm{~g} / \mathrm{L}$ ). Motility rate and motility time did not differ between T1 and T2 and were lower than fresh semen. The number of normal sperm was significantly different in treatments T1 (15.1\%) and T2 (21.9\%), and both showed a reduction in the percentage of normal sperm compared to fresh semen (57.4\%). The values found for the rates of fertilization and hatching, mitochondrial functionality and sperm DNA, did not differ between the treatments (T1 and T2). Regarding membrane integrity, there was a higher percentage of spermatozoa with intact membranes in T1 (53.4\%) than T2 (43.7\%). The extender solutions, combined with $10 \%$ DMSO, maintained the sperm DNA intact in almost all the C. macropomum sperm cells, however there was a loss in their functionality.

As soluções crioprotetoras são utilizadas para proteger os espermatozoides das alterações causadas por baixas temperaturas durante o processo de criopreservação. Avaliamos a qualidade do sêmen de Colossoma macropomum após o congelamento, utilizando dimetilsulfóxido (DMSO) como crioprotetor, combinado com duas soluções diluidoras (T1 - Solução 1: Glicose 90,0 g/L, Citrato de Sódio 6,0 g/L, EDTA 1,5 g/L, Bicarbonato de Sódio 1,5 g/L, Cloreto de Potássio 0,8 g/L, Sulfato de Gentamicina $0,2 \mathrm{~g} / \mathrm{L}$, e T2 - Solução 2: Glicose $90,0 \mathrm{~g} / \mathrm{L}, \mathrm{ACP}(\mathrm{B}-104$ 10,0 g/L). A taxa de motilidade (\%) e o tempo de motilidade (s) não diferiram entre T1 e T2, porém foram mais baixos do que no sêmen fresco. O número de espermatozoides normais foi significativamente diferente nos tratamentos T1 $(15,1 \%)$ e T2 $(21,9 \%)$, e ambos mostraram uma redução na porcentagem de espermatozoides normais, comparado ao sêmen fresco (57,4\%). Os valores encontrados para as taxas de fertilização e eclosão, funcionalidade mitocondrial e DNA do esperma, não diferiram entre os tratamentos (T1 e T2). Para a integridade da membrana, houve uma porcentagem mais elevada de espermatozóides com a membrana intacta em T1 $(53,4 \%)$ do que T2 $(43,7 \%)$. As soluções diluentes combinadas com DMSO a 10\% preservaram o DNA espermático intacto em quase todas as células do sêmen de C. macropomum, mas houve perda na funcionalidade dos mesmos.

Keywords: Cryopreservation, Cryoprotectant solution, Mitochondrial functionality, Motility, Spermatic DNA.

\section{Introduction}

Colossoma macropomum (Cuvier, 1816) as great relevance to the Brazilian fish chain as it is the principle native species produced in Brazil (Brasil, 2012), and its potential for growth and satisfactory development in tropical climates is constantly highlighted (Melo et al., 2001; Izel \& Melo, 2004). On the other hand, the asynchrony between males and females is a feature that makes it difficult to reproductive efficiency in this species (Galo, 2013), and this impasse can be resolved with the use of cryopreserved semen.

\footnotetext{
${ }^{1}$ Departamento de Zootecnia, Grupo de Pesquisa Aquam, Universidade Federal do Rio Grande do Sul, $91540-000$ Porto Alegre, RS, Brazil. (RRFG) raycongarcia@live.com (corresponding author), (ACNV) anacarina.vasconcelos@hotmail.com, (ERO) oberst@vortex. ufrgs.br, (ASVJ) varelajras@gmail.com, (DPSJ) danilo.streit@ufrgs.br

${ }^{2}$ Faculdade de Medicina Veterinária e Zootecnia (FAMEZ), Universidade Federal de Mato Grosso do Sul, 79074-460 Campo Grande, MS, Brazil. jayme.peixegen@gmail.com

${ }_{3}^{3}$ Instituto de Ciências Biológicas, Universidade Federal do Rio Grande, 96203-000 Rio Grande, RS, Brazil. antoniovarela@furg.br

${ }^{4}$ Departamento de Patologia Animal, Universidade Federal de Pelotas, 96010-900 Pelotas, RS, Brazil. corcinicd@gmail.com
} 
Cryopreservation of semen is a widely available biotechnology with a broad application in domestic fish farming, in areas such as: reduction of costs and risks in transporting animals, reduction of breeding stock, the transportation of either genetically modified gametes or gametes from animals selected in a breeding program, and also the elimination of asynchrony in gonadal maturity between males and females (Suquet et al., 2000; Maria et al., 2009; Viveiros et al., 2009; Viveiros et al., 2012). Concerning its practical and effective application in Brazil recorded the importance of cryopreservation for structuring the genetic improvement of the Colossoma macropomum program in the country.

Just as some native species have efficient protocols for freezing semen - Brycon insignis (Viveiros et al., 2011), $B$. orbignyanus (Maria et al., 2006) and B. nattereri (Oliveira et al., 2007) - the protocol to freeze the semen of C. macropomum was established recently (Maria et al., 2011), but it contains the egg yolk as external cryoprotector, whose substance can bring harm to sperm cells (Tiersch $\&$ Green, 2011). The extender solution most used in the protocols is solution of 5\% glucose (Ohta \& Izawa, 1996; Godinho \& Viveiros, 2011), which maintains osmotic pressure (isosmotic) in the sperm cell and thus prevents sperm activation. A practical and efficient extender solution made from commercial compounds is extremely important for the large scale standardization of sperm cryopreservation.

To minimize damage in the process of cryopreservation, cryoprotectants are combined with extender solutions in order to protect the sperm cells during the process of freezing and thawing (Squires et al., 1999). In any case, there are problems related to cryopreservation of reproductive cells, such as changing the physical structure of the sperm cell, which compromises cellular DNA and, therefore, the ability to fertilize (Labbe et al., 2001; Cabrita et al., 2005).

Thus, the aim of this study was to evaluate the quality of the sperm of $C$. macropomum cryopreserved with different enriched extender solutions.

\section{Material and Methods}

Location and animals used. This experiment was conducted in the Laboratories of Reproduction in Nova Mutum (MT) and Pimenta Bueno (RO). Subsequently, laboratory tests were conducted in the laboratories of microscopy, Universidade Federal do Rio Grande do Sul (Campus Veterinário - Laboratório de Microscopia) and Universidade Federal do Rio Grande (Laboratório de Reprodução Animal Comparada).

Twenty-six males and four females of C. macropomum were used in this experiment, which were kept in excavated ponds with recirculation water and oxygen dissolved rate of $6 \pm 1 \mathrm{mg} / \mathrm{l}$. Twice daily, the animals received a balanced diet, which was composed of a $32 \%$ crude protein feed.
Hormonal treatment and collection of semen. To be subjected to hormonal treatment, males were weighed and divided into five groups (5, 5, 5, 5 and 6 animals) to receive intramuscular injections of $0.7 \mathrm{mg}$ Ovopel $/ \mathrm{kg}$ per body weight, near the base of the dorsal fin. The semen collection occurred around $7 \mathrm{~h}$ after this treatment.

Before collection, the urogenital papilla was clean with a paper towel to avoid the previous activation of sperm cells by water or contamination by feces and urine. The semen was collected in sterile test tubes through light massage in coelomic wall in the craniocaudal direction and the samples were kept at room temperature $\left(23^{\circ} \mathrm{C}\right)$. Aliquot of $500 \mu \mathrm{L}$ of semen from each animal was used for the formation of a pool per group, in order to reduce the individual effect of males.

This semen pool was evaluated before and after the application of treatments that will be described later. Sperm concentration was achieved by diluting semen in $1000 \mathrm{uL}$ solution of formaldehyde buffered saline, and then the cell count was performed using a Neubauer chamber (Streit Jr. et al., 2009), obtaining an average concentration of $14.8 \pm$ $1.03 \times 10^{9}$ sperm per $\mathrm{ml}$ of ejaculated semen.

Evaluation of quantitative and qualitative parameters. Under light microscopy, the qualitative and quantitative parameters of the semen (40x) and sperm abnormalities (100x) were evaluated by a single reviewer and the methodologies used are describes below:

- Motility: a pool semen sample of $20 \mu \mathrm{L}$ was diluted and activated in $200 \mu \mathrm{L}$ of distilled water then placed between a slide and cover slip to be evaluated subjectively (Streit Jr. et al., 2008). Values from 0 to $100 \%$ for motility were assigned, depending on the movement of the sperm, at intervals of $10 \%$.

- Duration of motility: a stopwatch was activated as the semen was diluted in distilled water (to obtain the progressive motility) and it was stopped when the sperm flagella ceased its movement within the optical field.

- Sperm morphology: a semen sample from each animal was diluted in formalin-buffered saline solution. Then smears were made on the slides and stained with Rose Bengal in accordance with the recommendations of Streit Jr. et al. (2004) for fish. Subsequently, one hundred spermatozoa were assessed and primary and secondary damage were identified, according Miliorini et al. (2011) (Table 1).

Treatments. The solutions used for cryopreservation were composed of a extender solution and cryoprotectant agent (DMSO) (Table 2). The semen pools were subdivided into two groups and each group received one of the treatments (T1 - Solution 1 and T2 - Solution 2) at a ratio of 1: 4 (semen:solution).

Cryopreservation and thawing. The diluted semen was packaged into $0.25 \mathrm{~mL}$ straws and kept in a dry shipper cylinder $\left(-60^{\circ} \mathrm{C}\right)$ for $24 \mathrm{~h}$, at a freezing rate of 
approximately $-28{ }^{\circ} \mathrm{C} / \mathrm{min}$. After that time, the samples were stored in a tank of liquid nitrogen $\left(-196^{\circ} \mathrm{C}\right)$ according to the recommendations of Taitson et al. (2008), and they remained under these conditions for two weeks, until the moment of analysis.

The thawing of the samples was carried out by immersing the straws in water bath at $45^{\circ} \mathrm{C}$ for $8 \mathrm{sec}$ (Maria et al., 2011; Varela Junior et al., 2012a). After thawing, the semen samples were analyzed to obtain the qualitative and quantitative parameters, following the methodology described for fresh semen, and after that sperm functionality was analyzed.

Functional analysis of sperm. Mitochondrial function was assessed using the fluorescent staining rhodamine 123 (He \& Woods III, 2004). The sperm's membrane integrity was assessed using the fluorescent probes carboxyfluorescein diacetate - CFDA - and propidium iodide - PI - (Varela Junior et al., 2012a). As for the integrity of the DNA, the orange acridine probe was used (Varela Junior et al., 2012a). The assessments of mitochondrial function, membrane integrity and DNA were performed using an epifluorescence microscope (Olympus ${ }^{\circledR}$ BX 51, America INC, São Paulo Brazil) evaluating 200 cells/sample from $20 \mu \mathrm{L}$ solution on slides under a cover slip (18x18mm). Rates were expressed as the percentage of the intact/functional cells over the total cells analyzed.

Table 1. List of sperm damage evaluated in Colossoma macropomun. *Adapted from Miliorini et al. (2011).

\begin{tabular}{ll}
\hline Damage * & \\
\hline Primary & Secondary \\
\hline Macrocephaly & Free Normal Head \\
Microcephaly & Degenerated Tail \\
Degenerated Head & Proximal Droplet \\
Degenerated Midpiece & Distal Droplet \\
Broken Tail & \\
Curly Tail & \\
Folded Tail & \\
\hline
\end{tabular}

Table 2. Composition of extenders used in experiment with Colossoma macropomun.

\begin{tabular}{|c|c|c|}
\hline \multirow{2}{*}{ Components } & \multicolumn{2}{|c|}{ Solution } \\
\hline & 1 & 2 \\
\hline Glucose (g/L) & 90.0 & 90.0 \\
\hline Sodium Citrate (g/L) & 6.0 & . \\
\hline EDTA (g/L) & 1.5 & . \\
\hline Sodium Bicarbonate $(\mathrm{g} / \mathrm{L})$ & 1.5 & . \\
\hline Potassium Chloride (g/L) & 0.8 & . \\
\hline Gentamycin Sulphate $(\mathrm{g} / \mathrm{L})$ & 0.2 & . \\
\hline $\mathrm{ACP}^{\circledR}-104(\mathrm{~g} / \mathrm{L})$ & . & 10.0 \\
\hline DMSO (mL/L) & 100 & 100 \\
\hline
\end{tabular}

Hormonal treatment and collection of oocytes. To be subjected to hormonal treatment with carp pituitary extract (CCPE), each male was weighed and received intramuscular injections of 0.5 and $5.0 \mathrm{mg} \mathrm{kg}^{-1}$ of CCPE per body weight, near the base of the dorsal fin. There was an interval of $12 \mathrm{~h}$ between applications and semen collection occurred around $7 \mathrm{~h}$ after the last dose of CCPE.

Before collection, the urogenital papilla was clean with a paper towel and oocytes was collected in sterile containers through light massage in coelomic wall in the craniocaudal direction.

Evaluation of fertility and hatching rates. To analyze the fertilization rate, $1 \mathrm{~g}$ of oocyte and $250 \mu \mathrm{l}$ of thawed semen of $\mathrm{T} 1$ and $\mathrm{T} 2$ were placed in a disposable container, with an average of $9.73 \times 10^{5}$ sperm/oocyte. The number of oocytes contained in $1 \mathrm{~g}$ was calculated before being placed in contact with the semen.

Soon after, distilled water was added to activate the sperm and, $60 \mathrm{sec}$ later, embryonic structures were placed in 60-litre incubators with a continuous flow of water. After eight $\mathrm{h}$ of incubation (blastopore closure), at an average temperature of $26.5 \pm 0.9^{\circ} \mathrm{C}$, the fertilization rate was obtained.

For each treatment three counts were performed, evaluating viable (developing) and inviable (failed eggs) embryos. The average value of the three counts was stated as percentage of fertilized eggs.

After averaging the fertilization rate, one hundred viable embryos from each sample were maintained in experimental incubators $(300 \mathrm{~mL})$, which were made of plastic on the side and with a thin screen on the bottom to prevent the loss of oocytes. These containers were in a 200 liter tank for twelve more hours of incubation. The hatching rate was obtained from counting the number of larvae in each incubator.

Statistical analysis. Each pool received the treatment in triplicate and all variables were also evaluated three times. The analysis of normality for all dependent variables was performed using the Shapiro-Wilk test. Then, as the data did not behave normally, an analysis of variance was performed for nonparametric means using the KruskalWallis test. The different solvents were considered as independent variables, whilst sperm motility, duration of motility, fertilization rate, hatching rate, function of mitochondria, membrane integrity and sperm DNA were considered dependent variables. All data were expressed as mean \pm standard error of the mean (SEM). All analyzes were performed using Statistix 9.0 (2008) software.

\section{Results}

Sperm motility and morphology. The progressive motility (Mot), which is an important factor in determining the quality of cryopreserved semen, showed no statistical 
difference $(\mathrm{P}>0.05)$ between $\mathrm{T} 1 \quad(18.3 \pm 0.14 \%)$ and $\mathrm{T} 2$ $(18.5 \pm 0.13 \%)$, and both were much lower than motility of fresh semen was significantly different between treatments $(\mathrm{P}<0.05)$, and a reduction in the number of normal sperm cells (N Sperm) was observed in comparison to fresh semen $(57.7 \pm 2.0 \%)$ (Fig. 1a).

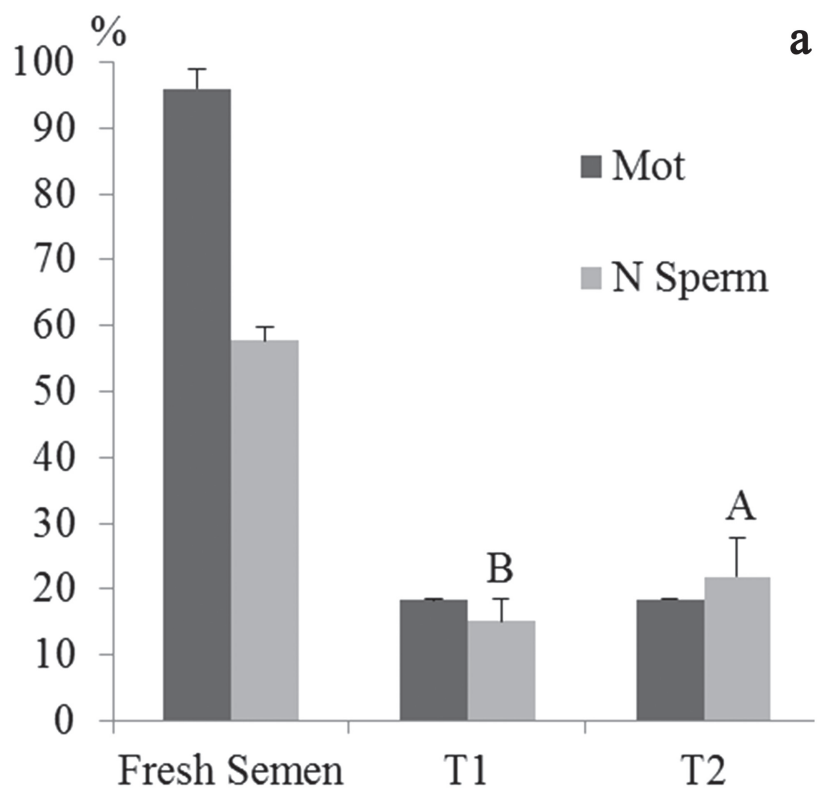

Duration of motility. The duration of the spermatozoa motility did not statistically differ $(\mathrm{P}>0.05)$ between treatments $\mathrm{T} 1(65.7 \pm 15.5 \mathrm{sec}), \mathrm{T} 2(53.6 \pm 20.5 \mathrm{sec})$ and fresh semen $(153.2 \pm 14.6 \mathrm{sec})$, although lower values have been observed, reaching below half in cryopreserved semen when compared with fresh semen (Fig. 1b).

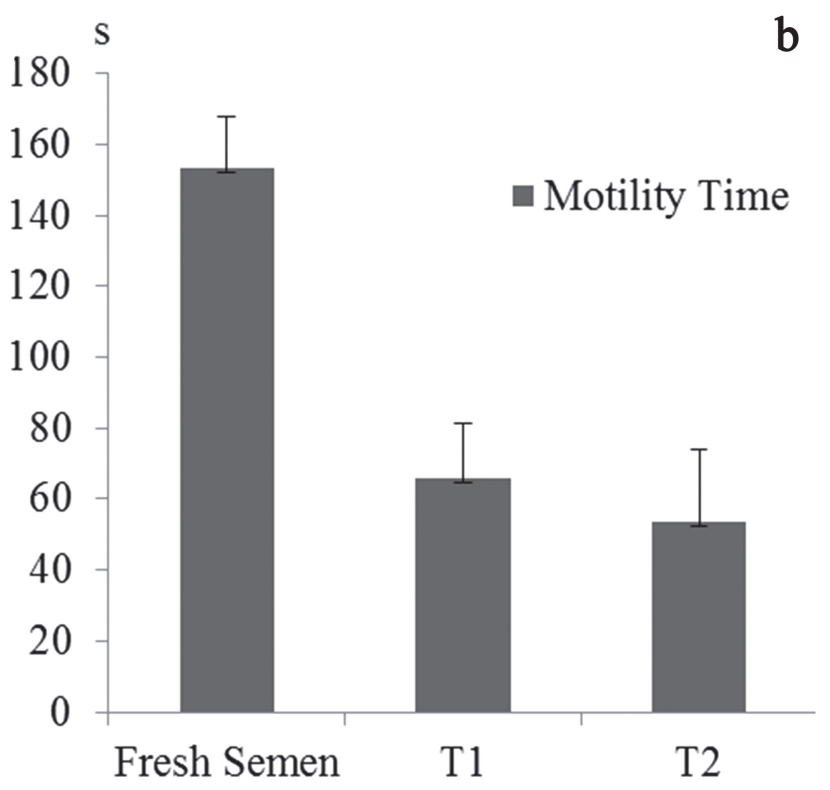

Fig. 1. (a) Mean and standard deviation of Progressive Motility (Mot) and Normal Sperm (N Sperm) and (b) Motility Time (TMot) of Colossoma macropomum, fresh and frozen, with two extenders (T1 - Solution 1 and T2 - Solution 2). Evaluated using the Kruskal-Wallis non-parametric test.

Rates of fertilization and hatching. Fertilization rates (Fert) and hatching (Hat) are also important indicators of semen quality. In this study these variables were no significant differences $(\mathrm{P}>0.05)$ between the treatments tested, with fertilization and hatching rates of $25.1 \pm 10.79 \%$ and $82.2 \pm 16.08 \%$ in $\mathrm{T} 1$, and $15.9 \pm 9.03 \%$ and $64.3 \pm 29.42$ $\%$ in $\mathrm{T} 2$, respectively (Fig. 2).

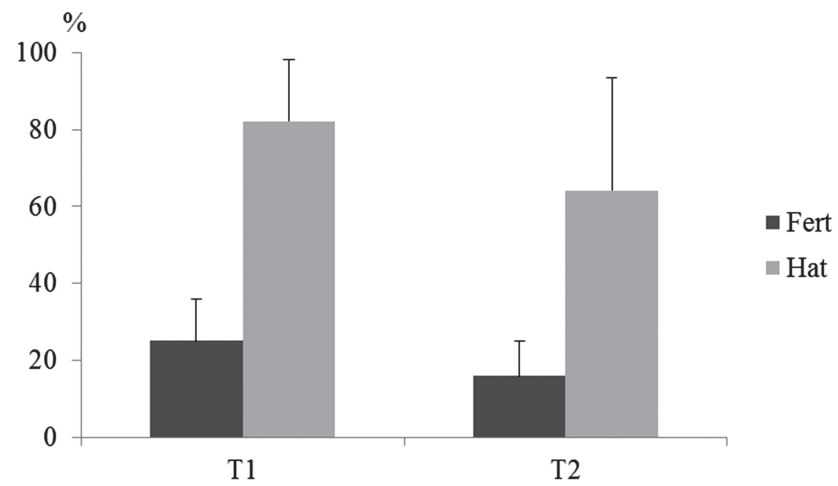

Fig. 2. Mean and standard deviation of the Fertilization Rate (Fert) and Hatching Rate (Hat) of Colossoma macropomum semen frozen with two extenders (T1 - Solution 1 and T2 - Solution 2). Evaluated using the Kruskal-Wallis nonparametric test.
Sperm damage. By observing the incidence of damage to sperm that have undergone the process of cryopreservation, we noted a higher percentage of primary damage $(62.13 \pm 8.59 \%$ and $55.20 \pm 8.35 \%)$ than secondary damage $(22.73 \pm 7.71 \%$ and $22.73 \pm 7.36 \%$ ) between treatments $\mathrm{T} 1$ and $\mathrm{T} 2$, respectively.

The damage of curly tail (CT) and broken tail (BT) were the most present of the primary damage classified (Fig. 3a).

Of the damage classified as secondary (Fig. 3b), the degenerate tail (DT) was the most common. We can, therefore, attest that cryopreservation mainly affected the final third of the sperm cell.

Membrane integrity, mitochondrial functionality and DNA integrity. In the epifluorescence microscopy analysis there was a statistical difference $(\mathrm{P}<0.05)$ for membrane integrity (Memb Int), which showed an integrity of between $53.4 \pm 6.27 \%$ and $43.7 \pm 5.61 \%$ for $\mathrm{T} 1$ and $\mathrm{T} 2$ respectively. Regarding the mitochondrial functionality (Mit Fun), there was no statistical difference $(\mathrm{P}>0.05)$ between treatments $\mathrm{T} 1$ $(46.8 \pm 7.49 \%)$ and $\mathrm{T} 2(46.8 \pm 21.27 \%)$.

The analysis of the DNA integrity (DNA Int) showed a high incidence of intact DNA in the two treatments (T1- 99.1 $\pm 1.83 \%$ and $\mathrm{T} 2-98.8 \pm 1.19 \%$ ), indicating the efficiency of cryoprotectants to preserve the genome of the sperm cell, even after the stress of freezing (Fig. 4). 

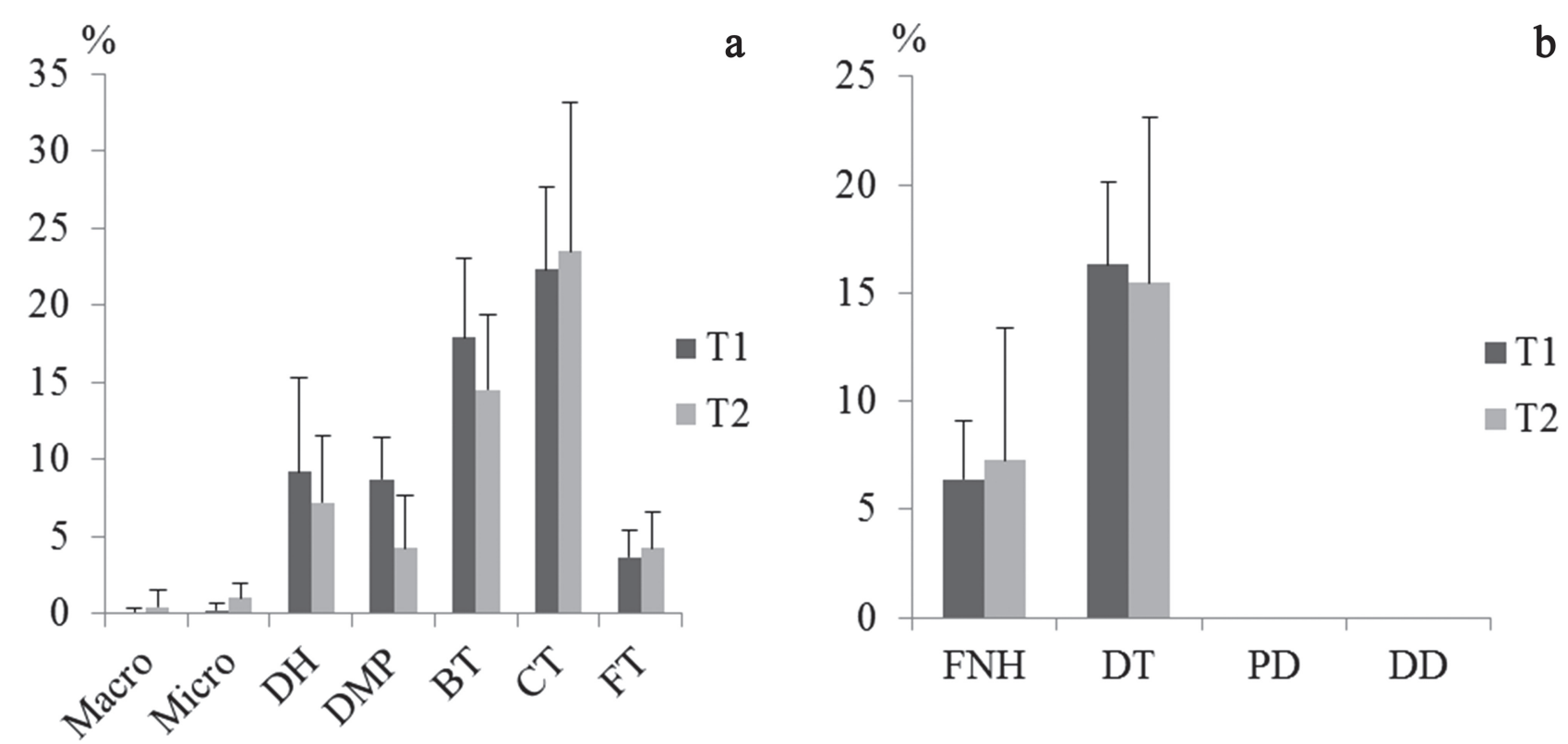

Fig. 3. The average percentage of damage found in frozen semen of Colossoma macropomum in different treatments. (a) Primary damage: Macrocephaly (Macro); Microcephaly (Micro); Head Degeneration (HD); Degenerated Midpiece (DMP); Curly Tail (CT); Broken Tail (BT); Folded Tail (FT). (b) Secondary damage: Degenerated Tail (DeT); Free Normal Head (FNH); Distal Droplet (DD); Proximal Droplet (PD).

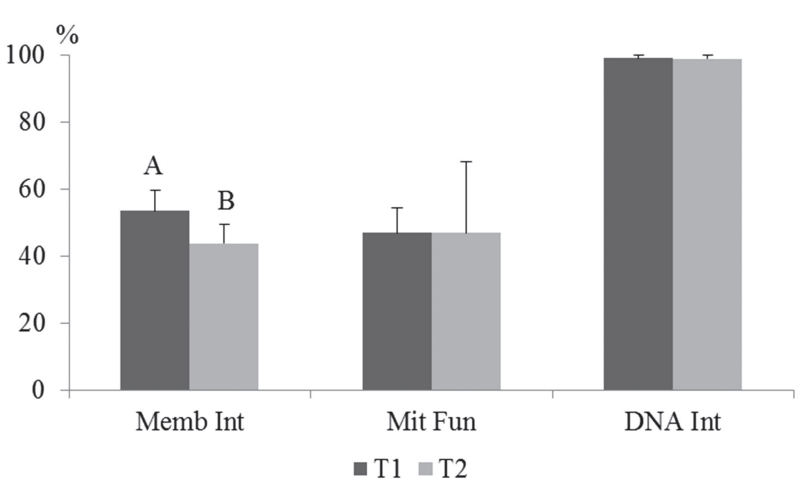

Fig. 4. Mean and standard deviation of percentage of Membrane Integrity (Memb Int), Mitochondria Functionality (Mit Fun) and DNA Integrity (DNA Int) observed in Colossoma macropomum sperm after cryopreservation. Evaluated using the Kruskal-Wallis non-parametric test.

\section{Discussion}

In general, after cryopreservation, there was a significant loss of C. macropomum sperm quality due to the osmotic stress imposed on sperm cells during this process. Although there was a difference between the treatments with regard to the integrity of the membrane, the cryoprotectant solutions (T1 - Solution 1 and T2 - Solution 2) did not effectively preserve the sperm structure, and less than $50 \%$ of the sperm cells retained their functional mitochondria. Due to the reduction of sperm functionality after cryopreservation, other parameters were directly affected, such as the rate and duration of motility, sperm morphology and, consequently, fertilization and hatching rates. Cryopreserved samples should have more than 50\% viable sperm and sperm motility to get good results (Maria et al., 2011), percentage not found in the present study after cryopreservation (variation around $18 \%$ motility). A reduction of more than $50 \%$ in sperm motility and motility time of cryopreserved semen compared to fresh semen certifies that the cryoprotectant solutions examined were not particularly effective in preserving the integrity of the sperm. It is important to note that the damages found may occur due to several factors such as the freezing and thawing rates, the storage container and the incorporation of the diluent solution by freezing sperm cell (Maria et al., 2009).

Since changes in mitochondrial rings and the sperm mid-piece decrease cellular ATP production (Yao et al., 2000), it is possible that the reduction in membrane integrity and functionality of the mitochondria affected the ability of the C. macropomum sperm to produce the energy needed to move. The reduction in the percentage of normal spermatozoa in the tested treatments confirms the harmful processes caused by cryopreservation technique. It is noteworthy that a reference value of morphological changes, by which fresh or cryopreserved semen can be judged unsuitable, still does not exist for fish (Miliorini, 2006). The values observed for different species are very disparate, making possible comparisons difficult or inaccurate.

In a study of the species Prochilodus lineatus, Miliorini et al. (2011) did not observe a percentage of pathological spermatozoa above $24.3 \%$ using DMSO + BTS $^{\circledR}$. On the 
other hand, the values obtained here are similar to those obtained by Streit Jr. et al. (2009), whose study reported $68.5 \%$ sperm pathologies in the semen of Piaractus mesopotamicus, using DMSO combined with glucose and egg yolk. According to Fabbrocini et al. (2000), the toxicity of cryoprotectants and the inefficiency of the cryopreservation process are linked to the leading causes of damage suffered by sperm cells.

None of extender solutions combined with the cryoprotectant DMSO were effective for the sperm cryopreservation of C. macropomum. A similar study with the same species, which combined DMSO + BTS $^{\circledR}$ in cryopreservation, also resulted in low rates of motility, around 20\%, and motility time of around $29.7 \mathrm{sec}$ (Varela Junior et al., 2012b). However, in another study with $C$. macropomum where the combination of dimethylformamide $(\mathrm{DMF})+\mathrm{BTS}^{\circledR}$ was tested, the results were higher, with values of around $64 \%$ for motility and $77.1 \mathrm{sec}$ motility time (Varela Junior et al., 2012a).

Despite the morphological changes, the decrease of membrane integrity and the fall in mitochondrial functionality, DNA integrity was maintained almost entirely in the cryopreserved semen. When there is increased fragmentation of the sperm DNA, there is probably a negative impact on the fertilization and hatching rates, in addition to endangering embryonic development (Varela Junior et al., 2012a). The percentage of sperm cells with intact DNA was higher than in the study by Varela Junior et al. (2012a), who found $73.1 \%$ and $43.3 \%$ of intact spermatozoa using DMF and DMSO associated with BTS ${ }^{\circledR}$, respectively.

During the reproductive period the seminal qualitative parameters vary significantly in C. macropomum (Galo, 2013). Thus, the spermatozoa which are immature or aged are more susceptible to injury caused by cryopreservation. From a qualitative point of view, as for the maturity of sperm C. macropomum, it is possible that they were in their best state. An indication of young sperm in mammals is microcephaly (Herman et al., 1994), whose anomaly occurred in less than $1.0 \%$ of the treatments in this results. Moreover, the cytoplasmic droplet in mammals may be indicative of aged sperm, but its presence was hardly detected in this work. Furthermore, less than $10 \%$ of the sperm were classified as having a degenerate head, confirming that the cryopreservation process did not harm the sperm from a genetic point of view. It is noteworthy that in mammals, abnormalities in the sperm head can cause low levels of fertility and a low hatching rate (Freneau, 2011).

The it is likely that the low fertilization rate in both treatments is the consequence of the changes induced by the cryopreservation process, such as reducing the motility rate and the duration of motility, increasing sperm pathologies (especially the tail), changes in membrane and mitochondrial functionality.

In the present study, it is likely that the low fertilization rate found in both treatments, is a result of changes brought about by cryopreservation, such as reducing the rate and duration of motility, increased sperm pathologies (especially the tail), and changes in the functionality of mitochondrial membrane. In studies with Prochilodus scrofa (Kavamoto et al., 1999) and P. lineatus (Miliorini et al., 2011) it was reported that sperm abnormalities, particularly in the tail, affected the sperm fertilization rate due to its irregular movement. In conclusion, the tested cryoprotectant solutions containing different extenders were partially effective in the structural protection of sperm cells during the freezing process, maintaining the integrity of the C. macropomum sperm DNA.

\section{Acknowledgments}

Thanks to the Piscicultura Boa Esperança (RO) and Piscicultura Buritis (MT) for their assistance and support in conducting this study.

\section{References}

Brasil, Ministério da Pesca e Aquicultura. 2012. Boletim estatístico da pesca e aquicultura, Brasil 2010. Brasília, DF, 2012, 128p.

Cabrita, E., V. Robles, S. Cuñado, J. C. Wallace, C. Sarasquete \& M. P. Herráez. 2005. Evaluation of gilthead sea bream, Sparus aurata, sperm quality after cryopreservation in $5 \mathrm{ml}$ macrotubes. Cryobiology, 50: 273-284.

Fabbrocini, A., S. L. Lavadera, S. Rispoli \& G. Sansone. 2000. Cryopreservation of seabream (Sparus aurata) spermatozoa. Cryobiology, 40: 46-53.

Freneau, G. E. 2011. Aspectos da morfologia espermática em touros. Revista Brasileira de Reprodução Animal, 35: 160170.

Galo, J. M. 2013. Avaliação da qualidade dos gametas de tambaqui (Colossoma macropomum) ao longo da estação reprodutiva. Unplubished PhD. Thesis. Programa de Pós-Graduação em Zootecnia, Universidade Estadual de Maringá, Maringá, 89p.

Godinho, H. P. \& A. T. M. Viveiros. 2011. Current status of sperm cryopreservation of Brazilian Characiform fishes. Pp. 875884. In: Tiersch, T. R. \& C. C. Green (Eds.). Cryopreservation in aquatic species. $2^{\text {nd }}$ ed. Baton Rouge, LA. The World Aquaculture Society.

He, S. \& L. C. Woods III. 2004. Effects of dimethyl sulfoxide and glycine on cryopreservation induced damage of plasma membranes and mitochondria to striped bass (Morone saxatilis) sperm. Cryobiology, 48: 254-262.

Herman, H. A., J. R. Mitchell \& G. A. Doak. 1994. The artificial insemination and embryo transfer of dairy and beef cattle. Interstate Illinois Publisher, 392p.

Izel, A. C. U. \& L. A. S. Melo. 2004. Criação de tambaqui (Colossoma macropomum) em tanques escavados no Estado do Amazonas. Manaus, Embrapa Amazônia Ocidental, 20p. (Embrapa Amazonia Ocidental, Documento 32).

Kavamoto, E. T., V. H. Barnabe, B. E. S. Campos \& E. F. Andrade-Talmelli. 1999. Anormalidades morfológicas nos espermatozóides do curimbatá, Prochilodus scrofa Steindachner, 1881 (Osteichthyes, Characiformes, Prochilodontidae). Boletim do Instituto de Pesca, 25: 61-66. 
Labbe, C., A. Martoriati, A. Devaux \& G. Maisse. 2001. Effect of sperm cryopreservation on sperm DNA stability and progeny development in rainbow trout. Molecular Reproduction and Development, 60: 397-404.

Maria, A. N., H. C. Azevedo \& P. C. F. Carneiro. 2009. Criopreservação de sêmen de peixes no contexto do agronegócio da piscicultura. Pp. 47-63. In: Tavares-Dias, M. (Org.). Manejo e sanidade de peixes em cultivo. Macapá, AP, Embrapa Amapá.

Maria, A. N., H. C. Azevedo \& P. C. F. Carneiro. 2011. Protocolo para criopreservação do sêmen de Tambaqui (Colossoma macropomum). Aracaju, SE, Embrapa Tabuleiros Costeiros, 8p. (Embrapa Tabuleiros Costeiros, Documento 112).

Maria, A. N., A. T. M. Viveiros, R. T. F. Freitas \& A. V. Oliveira. 2006. Extenders and cryoprotectants for cooling and freezing of piracanjuba (Brycon orbignyanus) semen, an endangered Brazilian teleost fish. Aquaculture, 260: 298-306.

Melo, L. A. S., A. C. U. Izel \& F. M. Rodrigues. 2001. Criação de tambaqui (Colossoma macropomum) em viveiros de argila/ barragens no Estado do Amazonas. Manaus, AM, Embrapa Amazônia Ocidental, 18p. (Embrapa Amazônia Ocidental, Documento 18).

Miliorini, A. B. 2006. Ativadores e concentrações de Metanol e dimetilsulfóxido na qualidade do sêmen criopreservado de curimba (Prochilodus lineatus). Unpublished Master's Degree Dissertation, Universidade Federal de Lavras, Lavras, 99p.

Miliorini, A. B., L. D. S. Murgas, P. V. Rosa, G. Oberlender, G. J. M. Pereira \& D. V. Costa. 2011. A morphological classification proposal for curimba (Prochilodus lineatus) sperm damages after cryopreservation. Aquaculture Research, 42: 177-187.

Ohta, H. \& T. Izawa. 1996. Diluent for cool storage of the Japanese eel (Anguilla japonica) spermatozoa. Aquaculture, 142: 107118.

Oliveira, A. V., A. T. M. Viveiros, A. N. Maria, R. T. F. Freitas \& Z. A. Izaú. 2007. Sucesso do resfriamento e congelamento de sêmen de pirapitinga Brycon nattereri. Arquivo Brasileiro de Medicina Veterinária e Zootecnia, 59: 1509-1515.

Squires, E. L., B. W. Pickett, J. K. Graham, D. K. Vanderwall, P. M. McCue \& J. E. Bruemmer. 1999. Cooled and frozen stallion semen: animal reproduction and biotechnology laboratory. Fort Collins, CO, Colorado States University. Pp 90.

Streit Jr., D. P., G. V. Moraes, R. P. Ribeiro, J. A. Povh, E. D. Souza \& C. A. L. Oliveira. 2004. Avaliação de diferentes técnicas para coloração de sêmen de peixes. Arquivos de Ciências Veterinárias e Zoologia da UNIPAR, 7: 157-162.

Streit Jr., D. P., A. C. Oliveira, R. P. Ribeiro, R. N. Sirol, G. V. Moraes, J. M. Galo \& M. Digmayer. 2009. Motilidade, vigor e patologia seminal in natura e pós criopreservação de Piaractus mesopotamicus. Boletim de Instituto de Pesca, 35: 159-167.
Streit Jr., D. P., R. N. Sirol, R. P. Ribeiro, G. V. Moraes, L. D. M. Vargas \& A. L. Watanabe. 2008. Qualitative parameters of the piapara semen (Leporinus elongatus Valenciennes, 1850). Brazilian Journal of Biology, 68: 373-377.

Suquet, M., C. Dreanno, C. Fauvel, J. Cosson \& R. Billard. 2000. Cryopreservation of sperm in marine fish. Aquaculture Research, 31: 231-243.

Taitson, P. F., E. Chami \& H. P. Godinho. 2008. Gene banking of the neotropical fish Leporinus obtusidens (Valenciennes, 1836): a protocol to freeze its sperm in the field. Animal Reproduction Science, 105: 283-291.

Tiersch, T. R. \& C. C. Green. (Eds.). 2011. Cryopreservation in aquatic species. $2^{\text {nd }}$ ed. Baton Rouge, LA, World Aquaculture Society, 1034p. (Advances in World Aquaculture, v. 7).

Varela Junior, A. S., C. D. Corcini, S. M. M. Gheller, R. D. Jardim, T. Lucia Jr., D. P. Streit Jr. \& M. R. C. Figueiredo. 2012a. Use of amides as cryoprotectants in extenders for frozen sperm of tambaqui, Colossoma macropomum. Theriogenology, 78: 244-251.

Varela Junior, A. S., C. D. Corcini, D. P. Streit Jr., G. Rizzoto, R. D. Jardim, T. Lucia Jr. \& M. R. C. Figueiredo. 2012b. Efeito crioprotetor de diferentes concentrações do dimetilsulfóxido no congelamento de sêmen de Tambaqui Colossoma macropomum. Atlântica, 34: 129-137.

Viveiros, A. T. M., T. B. Amaral, L. H. Orfão, Z. A. Isaú, D. Caneppele \& M. C. Leal. 2011. Sperm cryopreservation of tiete tetra Brycon insignis (Characiformes): effects of cryoprotectants, extenders, thawing temperatures and activating agents on motility features. Aquaculture Research, 42: 858-865.

Viveiros, A. T. M., Z. A. Isaú, D. Caneppele \& M. C. Leal. 2012. Sperm cryopreservation affects postthaw motility, but not embryogenesis or larval growth in the Brazilian fish Brycon insignis (Characiformes). Theriogenology, 78: 803-810.

Viveiros, A. T. M., L. H. Orfão, A. N. Maria \& I. B. Allaman. 2009. A simple, inexpensive and successful freezing method for curimba Prochilodus lineatus (Characiformes) semen. Animal Reproduction Science, 112: 293-300.

Yao, Z., L. W. Crim, G. F. Richardson \& C. J. Emerson. 2000. Motility, fertility and ultrastructural changes of ocean pout (Macrozoarces americanus L.) sperm after cryopreservation. Aquaculture, 181: 361-375.

Submitted September 17, 2014

Accepted May 18, 2015 by Bernardo Baldisserotto

Published September 25, 2015 
